\title{
Infeksi dan Tingkat Penyebaran Parasit Zoonosis Cacing Hati (Fasciola sp.) Pada Sapi Di Kabupaten Lombok Tengah dan Lombok Timur
}

\section{(Infection and Distribution of Liver Fluke (Fasciola Sp) Zoonotic Parasite on Cattle in Central Lombok and East Lombok Districts)}

\author{
Wayan Wariata, Made Sriasih, Anwar Rosyidi, Muhamad Ali dan Sulaiman N. Depamede \\ Laboratorium Mikrobiologi dan Bioteknologi Fakultas Peternakan Universitas Mataram \\ Jl. Majapahit No.62 Mataram 83125, NTB, Indonesia \\ Email: wayanwariata@gmail.com
}

Diterima : 22 Oktober 2019/Disetujui : 25 Nopember 2019

\begin{abstract}
ABSTRAK
Salah satu faktor yang sangat mempengaruhi populasi dan produksi ternak adalah masalah penyakit dan parasit. Gejala serangan parasit seringkali tidak tampak dan kadang-kadang petani kurang menyadarinya. Cacing hati (Fasciola sp.) merupakan parasit zoonosis yang dapat menginfeksi berbagai macam hewan ternak ruminansia terutama sapi. Fasciola memiliki dua spesies utama yaitu hepatica dan gigantica. Penyebaran Fasciola $s p$. adalah daerah beriklim tropis basah yaitu di Asia dan Afrika. Fasciola sp. yang sering dijumpai di Indonesia adalah spesies gigantica, sedangkan spesies hepatica sering terdeteksi pada sapi-sapi impor. Untuk mengetahui infeksi dan tingkat penyebaran Fasciola gigantica dan Fasciola hepatica pada ternak sapi di kabupaten Lombok Tengah dan Lombok Timur maka dilakukan survei, pengamatan dan pengambilan sampel organ hati sapi di pasar-pasar daging yang ada pada dua daerah tersebut. Pada masing-masing daerah diambil 3 lokasi pasar daging, yaitu di kabupaten Lombok Tengah: pasar Praya, pasar Mantang dan pasar Kopang; di kabupaten Lombok Timur: pasar Selong, pasar Masbagik dan pasar Terara. Pada masing-masing pasar, pengamatan dan pengambilan sampel diulang sebanyak 3 kali pada 3 orang pedagang. Selanjutnya sampel diamati di laboratorium untuk mengetahui adanya cacing hati dan kerusakan hati sapi. Hasil penelitian menunjukkan bahwa, sapi-sapi dan daging sapi yang diperjual belikan di pasar-pasar Lombok Tengah dan Lombok Timur terinfeksi parasit cacing hati (Fasciola $s p$.), dengan tingkat infeksi yang masih rendah, yaitu antara 1,3 sampai 2,3. Di samping itu, warna dan tekstur hati sapi yang diperjual belikan di pasar-pasar Lombok Tengah dan Lombok Timur relatif masih baik dan layak dikonsumsi.
\end{abstract}

Kata kunci : Sapi, Makroskopis hati, Zoonosis, Cacing Hati (Fasciola sp.)

\begin{abstract}
The factor that greatly influences livestock population and production is the problem of diseases and parasites. Symptoms of parasitic attacks are often not visible and sometimes farmers are not aware of it. Liver fluke (Fasciola sp.) are zoonotic parasites that can infect a variety of ruminant livestock, especially cattle. Fasciola has two main species namely hepatica and gigantica. Fasciola sp. is distributed well in a wet tropical climate, namely in Asia and Africa. Fasciola sp. which is often found in Indonesia is the gigantica species, while the hepatica species is often detected in imported cows. To find out the infection and the distribution level of Fasciola sp in cattle in Central Lombok and East Lombok districts, a survey, observation and sampling of beef liver in meat markets in these two regions were carried out. In each region 3 locations of the meat market were taken; Praya, Mantang and Kopang market for the district of Central Lombok; Selong, Masbagik and Terara market for the district of East Lombok. In each market, observation and sampling were repeated 3 times with 3 traders. All samples collected were then observed and tested in a laboratory to determine the liver worms and the damage to cow liver. The results show that cows and beef traded in Central and East Lombok markets were infected with Fasciola sp., with infection level that was still low, between 1.3 and 2.3. In addition, the color and texture of beef liver traded in Central Lombok and East Lombok markets were relatively good and safe for consumption with proper cooking.
\end{abstract}

Keywords : Cattle, Liver Macroscopy, Zoonotic, Liver Fluke (Fasciola Sp) 


\section{PENDAHULUAN}

Sapi yang biasa dipelihara oleh peternak di wilayah Nusa Tenggara Barat khususnya Lombok Tengah dan Lombok Timur adalah didominasi oleh sapi Bali. Sapi Bali merupakan sapi asli Indonesia yang memiliki berbagai keunggulan diantaranya memiliki tingkat kesuburan yang tinggi, kemampuan adaptasi yang baik terhadap lingkungan dan persentase beranak yang mencapai $80 \%$ (Soares dan Dryden, 2011). Disamping itu, sapi Bali mampu menghasilkan karkas dan daging berkualitas baik.

Salah satu faktor yang menyebabkan penurunan populasi dan produktivitas sapi adalah masalah penyakit dan infeksi parasit zoonosis yang gejalagejalanya seringkali kurang terdeteksi oleh petani peternak. Penyakit dapat terjadi biasanya berada di daerah tropis yang memiliki tingkat kelembaban yang cukup tinggi seperti daerah Nusa Tenggara Barat dengan kelembaban $65-68 \%$.

Penyakit yang sering menyerang sapi di daerah Nusa Tenggara Barat terutama pulau Lombok adalah daerah endemis penyakit cacing hati (Fasciola $s p$.). Fasciola $s p$. juga dapat menyebabkan penyakit pada manusia (zoonosis) yang disebut fasicioliosis. Hewan-hewan lain juga dapat tertular dan pernah dilaporkan yaitu kuda, babi, anjing, rusa, zebra, kelinci dan marmot, yang pada alkhirnya juga dapat menyerang manusia (Nasser et al.,2008; Eslami et al.,2009). Fascioliosis pada ternak terutama sapi yang disebabkan kista Fasciola $s p$ melalui induk semang sementara yaitu siput Lymnea sp., berikutnya cercaria atau meta cercaria menempel pada rumput lalu termakan oleh sapi. Cacing muda merusak jaringan hati, cacing dewasa diam dan bertelur di saluran empedu (Mas-Coma et al.,2005; Wiedosari, 2006)).

Fasciola sp. terdiri dari $F$. gigantica dan $F$. hepatica yaitu penyebab Fasciolosis pada ternak dan manusia. Perbedaan morfologi kedua spesies Fasciola tersebut karena adanya perbedaan pada hubungan antara inang dan parasit, inang perantara serta susunan DNA (Spithill et al.,1999). $F$. gigantica dewasa lebih panjang, memiliki pengisap ventral lebih besar, dan testis anterior lebih banyak jika disbanding dengan $F$. hepatica, tetapi bentuk telur kedua cacing ini serupa, meskipun telur dari $F$. gigantica sedikit berukuran lebih besad dari F. hepatica (Muller, 2002; Periago et al., 2006).

Penyakit cacing hati (fasciolosis) dapat mengganggu pertumbuhan ternak sehingga dapat menyebabkan kerugian peternak yang disebabkan biaya pemeliharaan dan perawatan kesehatan ternak tidak seimbang dengan harga jual ternak. Selain itu manusia juga dapat terjangkit penyakit cacing hati karena masih banyak peternak atau masyarakat yang sering mengkonsumsi daging setengah matang.

Fasciolosis sangat sulit dideteksi gejalanya oleh peternak, tetapi sangat merugikan peternak karena prevalensinya yang tinggi dengan gejala penurunan bobot badan, produksi susu pada sapi perah dan fertilitas ternak (Periago et al., 2006). Fasciolosis juga dapat menginfeksi manusia karena sifatnya zoonosis di berbagai penjuru dunia, sehingga penyakit ini telah dimasukkan ke dalam daftar penyakit-penyakit parasit paling penting di dunia oleh badan kesehatan dunia WHO (WHO, 2005). Fasciolosis dapat menginfeksi secara akut, subakut dan kronis. Infeksi bentuk akut disebabkan adanya migrasi cacing muda dalam jaringan hati yang menyebabkan kerusakan jaringan hati, dengan gejala ternak menjadi lemah, nafas cepat dan pendek, perut membesar disertai rasa sakit. Bentuk subakut tidak memperlihatkan gejala sama sekali, tetapi bisa menyebabkan kematian mendadak. Bentuk kronis terjadi saat cacing memcapai dewasa 4-5 bulan setelah infeksi dengan gejala anemia sehingga ternak menajdi 
lesu, lemah, nafsu makan menurun, cepat mengalami kelelahan, membran mukosa pucat, diare, oedema di antara sudut dagu dan bawah perut, ikterus dan kematian dapat terjadi dalam 1-3 bulan (Muller, 2002).

Usaha untuk menekan kerugian dan angka kesakitan ternak akibat infeksi cacing Fasciola sp. akan berhasil melalui program pengendalian yang didasarkan pada diagnosa dini. Diagnosa dini dimaksudkan untuk mengetahui lebih awal keberadaan cacing dalam tubuh sebelum meninmbulan perubahan patologis yang lebih berat. Diagnosa Fasciolosis dapat dilakukan secara sederhana yaitu pemeriksaan telur cacing pada feces (Estuningsih et al., 2004). Selain itu, diagnosa dilakukan dengan pengamatan dan pemeriksaan postmortem, atau pemeriksaan dilakukan pada bangkai ternak atau karkas di rumah potong hewan (RPH) dan di pasar-pasar daging untuk memeriksa cacing fasciola sp. pada organ hati secara langsung. Usaha ini dilakukan untuk mengetahui tingkat prevalensi dan penyebaran infeksi cacing fasciola. Penyebaran Fasciolosis di kota Mataram dan kabupaten Lombok Barat merata pada hampir setiap kecamatan (Wariata et al., 2015).

Pengcegahan dan pengobatan terhadap penyakit Fasciolosis sangat penting dilakukan terhadap ternak-ternak, disamping juga memberikan penyuluhan kepada para peternak bagaimana mengenali gejala-gejala klinis fascioliosis. Semakin cepat gejala-gejala terdeteksi maka semakin cepat pengobatan dapat dilaksanakan, sehingga dapat menghindari kerugian peternak.

\section{MATERIAL DAN METODA}

\section{Pengumpulan Sampel}

Sampel berupa organ hati sapi dikumpulkan di dua daerah yaitu kabupaten Lombok Tengah dan Lombok Timur, masing-masing 3 pasar daging sehingga berjumlah 6 pasar. Di kabupaten Lombok Tengah yaitu pasar Praya, pasar Mantang dan pasar Kopang, sedangkan di kabupaten Lombok Timur yaitu pasar Selong, pasar Masbagik dan pasar Terara. Di setiap pasar pengambilan sampel diulang sebanyak 3 kali sehingga jumlah seluruh sampel adalah 18. Deskripsi yang perlu dicatat pada saat pengambilan atau pembelian sampel adalah asal daging, waktu pemotongan sapi, warna dan tekstur organ hati. Setelah sampai di laboratorium, setiap sampel organ hati diiris-iris dan diperiksa untuk mengetahui keberadaan Fasciola sp.

\section{Analisa Data}

Interpretasi data hasil pengamatan dan pengukuran secara kuantitatif dan kualitatif. Data hasil uji di lapangan dan di laboratorium dianalisis secara deskriptif.

\section{HASIL DAN PEMBAHASAN}

\section{Infeksi dan Penyebaran Cacing Hati (Fasciola sp.)}

Penyebaran cacing hati dimanifestasikan dengan ditemukannya sejumlah cacing hati (Fasciola sp.) di dalam sampel di beberapa pasar, baik di kabupaten Lombok Tengah maupun di Lombok Timur. Jumlah Fasciola sp. yang ditemukan pada sampel di pasar-pasar dapat dilihat pada Tabel 1. berikut. 


\section{Tabel 1. Jumlah Cacing Hati (Fasciola sp.) Yang Ditemukan Dalam Sampel Hati Sapi Di pasar-pasar Lombok Tengah dan Lombok Timur (ekor).}

\begin{tabular}{|c|l|c|c|c|c|}
\hline \multirow{2}{*}{ Daerah } & \multirow{2}{*}{ Lokasi } & \multicolumn{2}{|c|}{ Pengambilan Sample Ke- } & \multirow{2}{*}{ Rata-Rata } \\
\cline { 2 - 6 } & & $\mathbf{1}$ & $\mathbf{2}$ & $\mathbf{3}$ & 2,3 \\
\hline \multirow{2}{*}{$\begin{array}{c}\text { Lombok } \\
\text { Tengah }\end{array}$} & Pasar Praya & 4 & 1 & 2 & 1,7 \\
\cline { 2 - 6 } & Pasar Mantang & 1 & 0 & 4 & 2,0 \\
\cline { 2 - 6 } & Pasar Kopang & 3 & 3 & 0 & 1,7 \\
\hline \multirow{2}{*}{$\begin{array}{c}\text { Lombok } \\
\text { Timur }\end{array}$} & Pasar Selong & 0 & 2 & 3 & 1,3 \\
\cline { 2 - 6 } & Pasar Masbagik & 1 & 3 & 0 & 0,3 \\
\cline { 2 - 6 } & Pasar Terara & 2 & 2 & 1 & \\
\hline
\end{tabular}

Pada Tabel 1 terlihat bahwa cacing hati (Fasciola sp.) ditemukan pada semua pasar baik di Lombok Tengah maupun di Lombok Timur. Keberadaan Fasciola sp. pada hati sapi biasanya diabaikan, baik oleh pedagang maupun konsumen. Mereka beranggapan bahwa Fasciola sp. hanya parasit, setelah dimasak dengan baik maka Fasciola sp. akan mati dan tidak memberikan dampak negatif pada kesehatan. Tentu saja anggapan ini keliru, karena yang berbahaya adalah larva Fasciola $s p$. yang berukuran sangat kecil. Jumlah rata-rata Fasciola sp. yang ditemukan dalam sampel hati berkisar antara 1,3 sampai 2,3 ekor. Nasser et al., 2008 dan Eslami et al., 2009, menyatakan bahwa penyakit yang menyerang sapi di daerah Nusa Tenggara Barat terutama pulau Lombok adalah daerah endemis cacing hati (Fasciola sp.). Walaupun jumlah ini termasuk kecil, tetap saja dinyatakan bahwa hati sapi yang diperjual belikan di pasarpasar Lombok Tengah dan Lombok Timur berasal dari sapi-sapi yang telah terinfeksi cacing hati (Fasciola sp.). Para pedagang mengatakan bahwa daging dan hati sapi yang dijualnya selain berasal dari Lombok Tengah dan Lombok Timur, juga berasal dari daerah lain di Nusa Tenggara Barat. Kenyataan ini mengindikasikan bahwa sistem pemeliharaan sapi-sapi di Lombok Tengah, Lombok Timur dan daerah sekitarnya masih kurang baik. Pemeliharaan masih bersifat semi intensif bahkan masih tradisional. Kenyataan tersebut sejalan dengan pendapat MasComa et al. (2005), yang menyatakan bahwa fasciolosis pada ternak terutama sapi yang disebabkan oleh kista Fasciola $s p$. melalui induk semang sementara yaitu siput Lymnea sp., berikutnya cercaria atau metacercaria menempel pada rumput yang akhirnya termakan oleh sapi, hal ini terjadi karena pemeliharaan sapi yang kurang intensif. Untuk menghindari hal-hal tersebut di atas, maka penyembelihan perlu melalui Rumah Potong Hewan (RPH) dan karkas beserta jeroannya diperiksa oleh petugas dari Dinas Peternakan setempat. Bagian hati yang ada cacingnya harus diambil dan dimusnahkan karena tidak layak untuk dokonsumsi.

\section{Warna dan Tekstur Sampel Hati Sapi}

Untuk mengetahui dan memastikan kesehatan suatu hewan ternak, salah satu indikatornya dapat dilihat atau diamati dari warna dan tekstur hatinya setelah pemotongan atau pemeriksaan post mortem. Sampel hatinya diamati sebelum diiris-iris (insfectio), setelah itu pemeriksaan juga dilakukan setelah dipotong dan diiris-iris (sectio) untuk mengetahui warna dan tekstur di bagian dalam. Pemeriksaan warna dan tekstur sampel hati tidak lebih dari sehari setelah pemotongan, lebih cepat lebih baik, agar hasil pemeriksaan yang diperoleh lebih terukur, akurat dan dapat dipertanggung jawabkan. Jarak antara rumah potong hewan (RPH) dengan pedagang yang ada di pasar-pasar sangat menentukan ketahanan kualitas daging dan hati sapi.

Warna hati sapi sejatinya adalah "merah hati" atau merah darah. Pada kasuskasus tertentu misalnya karena suatu penyakit warna hati sapi dapat berubah menjadi merah agak pucat sampai pucat kekuningan. Warna sampel hati sapi yang 
diamati di pasar-pasar Lombok Tengah dan Lombok Timur dapat dilihat pada Tabel 2 berikut ini. Tabel 2. Warna Sampel Hati Sapi Yang Diamati Di pasar-pasar Lombok Tengah dan
Lombok Timur

\begin{tabular}{|c|l|c|c|c|}
\hline \multirow{2}{*}{ Daerah } & \multirow{2}{*}{ Lokasi } & \multicolumn{3}{|c|}{ Pengambilan Sample Ke- } \\
\cline { 3 - 5 } & & $\mathbf{1}$ & $\mathbf{2}$ & $\mathbf{3}$ \\
\hline \multirow{3}{*}{ Lombok Tengah } & Pasar Praya & Merah pucat & Merah & Merah \\
\cline { 2 - 5 } & Pasar Mantang & Merah & Merah & Merah pucat \\
\cline { 2 - 5 } & Pasar Kopang & Merah & Merah & Merah \\
\hline \multirow{3}{*}{ Lombok Timur } & Pasar Selong & Merah pucat & Merah & Merah \\
\cline { 2 - 5 } & Pasar Masbagik & Merah & Merah & Merah \\
\cline { 2 - 5 } & Pasar Terara & Merah & Merah & Merah \\
\hline
\end{tabular}

Pada Tabel 2 di atas tertera bahwa warna sampel hati sapi yang diamati di pasar-pasar Lombok Tengah dan Lombok Timur terlihat rata-rata berwarna merah, walaupun di beberapa lokasi ditemukan sampel hati yang warnanya merah agak pucat.

Tetapi secara umum jika dilakukan pemeriksaan oleh petugas maka sampel hati masih layak untuk dikonsumsi. Perubahan warna sampel hati sapi dapat terjadi karena perubahan fisiologi fungsi hati. Pernyataan ini didukung oleh pendapat Tuasikal dan Suhardono (2006), bahwa Fasciolosis dapat berkembang menjadi kronis yang ditandai dengan gangguan fisiologi fungsi hati yang pada akhirnya dapat mengganggu metabolisme karbohidrat, lemak dan protein, dan dalam jangka panjang mengganggu pertumbuhan serta menurunkan bobot hidup ternak.

Tekstur sampel hati sapi dapat diketahui dengan cara melihat, memegang dan meraba. Indikator dari pemeriksaan tekstur hati adalah jika sampel hati dipegang dan ditekan-tekan akan terasa kenyal. Tekstur hati sangat ditentukan oleh waktu, akan berubah secara cepat menjadi lembek, kadang-kadang kaku seiring berjalannya waktu dan berbagai perlakuan terhadap sapi semasih hidup, seperti misalnya sebelum dipotong sapi diberi munum banyak yang dikenal dengan sapi gelonggongan. Tekstur sampel hati sapi yang diamati di pasar-pasar di Lombok Tengh dan Lombok Timur rata-rata bertekstur baik dan kenyal, walaupun di beberapa lokasi teksturnya sudak mulai lembek, seperti tertera pada Tabel 3 berikut ini.

Tabel 3. Tekstur Hati Sapi Yang Diamati Di pasar-pasar Lombok Tengah dan Lombok Timur

\begin{tabular}{|c|l|c|c|c|}
\hline \multirow{2}{*}{ Daerah } & \multirow{2}{*}{ Lokasi } & \multicolumn{3}{|c|}{ Pengambilan Sample Ke- } \\
\cline { 3 - 5 } & & $\mathbf{1}$ & $\mathbf{2}$ & $\mathbf{3}$ \\
\hline \multirow{3}{*}{ Lombok Tengah } & Pasar Praya & Baik, kenyal & Baik, kenyal & Baik, kenyal \\
\cline { 2 - 5 } & Pasar Mantang & Baik, kaku & Baik, kenyal & Baik, kaku \\
\cline { 2 - 5 } & Pasar Kopang & Baik, lembek & Baik, kenyal & Baik, kenyal \\
\hline \multirow{3}{*}{ Lombok Timur } & Pasar Selong & Baik, kenyal & Baik, kenyal & Baik, lembek \\
\cline { 2 - 5 } & Pasar Masbagik & Baik, kenyal & Baik, kenyal & Baik, kenyal \\
\cline { 2 - 5 } & Pasar Terara & Baik, lembek & Baik, kenyal & Baik, kenyal \\
\hline
\end{tabular}

Pada Tabel 3 di atas, tertera bahwa tekstur sampel hati sapi terlihat baik dan kenyal, walaupun di beberapa lokasi sudah ada yang lembek, ada juga yang kaku tetapi rata-rata masih layak dikonsumsi. Spithill et al. (1999), menyatakan bahwa Fasciolosis tidak memperlihatkan gejala klinis yang khas sehingga pencegahan dan 
pengendalian penyakit ini masih sangat kurang diperhatikan dan penyakit berkembang menjadi kronis yang ditandai dengan gangguan fisiologi fungsi hati akibat perubahan struktur jaringan hati. Hasil penelitian ini, secara makroskopis menunjukkan bahwa sapi-sapi yang ada di Lombok Tengah dan Lombok Timur terinfeksi Fasciola sp., walaupun demikian tidak sampai mempengaruhi warna dan tekstur hati sapi secara signifikan, sehingga jika dilakukan pemeriksaan oleh petugas dapat dikatakan masih layak dikonsumsi.

\section{KESIMPULAN DAN SARAN}

\section{Kesimpulan}

Berdasar hasil penelitian tersebut di atas dapat disimpulkan bahwa:

1. Sapi-sapi yang dipotong dan diperjual belikan di kabupaten Lombok Tengah dan Lombok Timur terinfeksi parasit cacing hati (Fasciola sp.), walaupun dengan tingkat infeksi yang masih rendah.

2. Warna dan tekstur hati dari sapisapi yang diperjual belikan di pasarpasar kabupaten Lombok Tengah dan Lombok Timur relatif masih baik sehingga masih layak untuk dikonsumsi.

3. Untuk menentukan layak tidaknya kualitas karkas dan jeroan maka perlu dilakukan pemeriksaan oleh petugas, kalau layak segera diberi cap stempel baru kemudian didistribusikan ke pasar-pasar.

\section{Saran}

Berdasar hasil penelitian yang telah dilaksanakan maka dapat disarankan bahwa:

1. Perlu dilakukan penelitian lebih lanjut dengan area penelitian di pasar-pasar tradisional yang lain.

2. Sistem dan tatalaksana pemeliharaan sapi perlu ditingkatkan menjadi lebih intensif untuk menghindari infeksi parasit cacing hati (Fasciola sp.)

3. Dinas Peternakan perlu mensyaratkan penyembelihan di RPH sehingga kualitas hati yang dikonsumsi bebas dari cacing, bagian yang tidak layak konsumsi dimusnahkan dan bebas dari infeksi bakteri.

\section{DAFTAR PUSTAKA}

Eslami, A., Hosseini S.H., and Meshgi, B. 2009. Animal Fasciolosis in North of Iran. Iran $\mathrm{J}$ Public Health. 38(4):132-135.

Estuningsih, S.E., Widjajanti, S., Adiwinata, G., and Piedrahita, D. 2004. Detection of Coproantigen by sandwich ELISA in Sheep Experimentally infected w with Fasciola gigantica. Trop Biomed 21(2):51-56.

Mas-Coma, S., Valero, M.A., and Bargues, M.D. 2005. Fasciolosis and Other Plant-borne Trematoda Zoonoses. Int. Journal Parasitol 35 : 12551278 .

Muller, R. 2002. Worms and Human Diseases. CABI International, Wallingford, Oxon, UK.

Nasser, A., Hussein, A., and Khalifa, RMA. 2008. Experimental Infections with Fasciola in Snails, Mice and Rabbits. Parasitol Res 102: 11651170.

Periago, M.V., Valero, M.A., Panova, M., and Mas-Coma, S. 2006. Phenotypic Comparison of Allopatric Population of Fasciola hepatica and Fasciola gigantica from European and African Bovines Using a Computer Image Analysis System (CIAS). Parasitol Res 99: 368-378 
Soares, F.S., and Dryden, G.M. 2011. A body condition Scoring System for Bali Cattle. Asian-Aust J Anim Sci, 24(11): 1587-1594.

Spithill, T.W., P.M. Smooker, D.B. Copeman. 1999. Fasciola gigantica: epidemiology, control, immunology and molecular biology. In: Dalton, J.P. (Ed), Fasciolosis. CAB International, Wallingford, pp. 465525.

Tuasikal, B.J. dan Suhardono. 2006. Pengaruh infeksi Fasciola gigantica (cacing hati) iradiasi terhadap gambaran darah kambing (Capra hircus Linn). JITV 11 (4): 317-323.
Wariata, W., M. Sriasih., dan A. Rosyidi. 2015. Prevalensi dan Tingkat Penyebaran Parasit Zoonosis Cacing Hati (Fasciola sp.) pada Sapi di Kota Mataram dan Kabupaten Lombok Barat. Laporan Penelitian Lembaga Penelitian Universitas Mataram.

WHO. 2005. Deworming for Health and Development. Report of the Third global meeting of the partners for parasite control. Geneva: World Health Organization; WHO/CDS/PVC/2005.14.

Wiedosari, E. 2006. Mekanisme imunologi dari resistensi domba ekor tipis terhadap infeksi Fasciola. Berita Biologi 8 (2): 99-105. 